\title{
ANATOMY OF POLITICAL PARTIES IN TIMOR-LESTE
}

Joao M. Saldanha

\section{Introduction}

While Fretilin, the main group to resist Indonesian dominance between 1975 and 1999, still dominates Timor-Leste (earlier, East Timor) politics overwhelmingly, the transition to democratic elections in 2001 under the authority of the United Nations Transitional Authority in East Timor (UNTAET) has witnessed the re-emergence of multi-party politics. While Fretilin maintains hold of more than 60 per cent of the seats in the fledgling legislature, representatives of the several minority parties also won seats. Of these, most have their origins in the initial emergence of Timor-Leste from Portuguese control in the 1970s, while others represent former factions of Fretilin. While Timor-Leste has faced many hurdles in its attempts to install multi-partyism and functioning democracy, not least from the spectre of a one-party state, the present composition of the National Parliament reflects these various interests vying for national influence.

Timor-Leste gained full independence only in May 2002, nearly three years after the overwhelming majority of Timor-Leste voted for independence in a UN referendum held on August 30, 1999. The referendum was followed by the tragic destruction of the country, inflicted by the Indonesian military and its supporters. In October 1999, UN Security Council Resolution No. 1272/1999 established UNTAET to prepare TimorLeste for independence as well as to oversee reconstruction efforts. One of UNTAET's major tasks was to create the foundations for a democratic Timor-Leste. ${ }^{2}$ To assist in achieving this goal, it organised elections for a Constituent Assembly, whose mandate was to write the Constitution of Timor-Leste.

Sixteen political parties registered to participate in the elections for the Constituent Assembly on August 30, 2001. Twelve gained enough votes to be represented in the Assembly. The clear winner was the Frente Revolucionaria Timor Leste Independente (Fretilin), which won 55 of the 88 seats. With this majority, Fretilin formed the Second 
Transitional Administration and dominated the process of drafting a constitution for the Democratic Republic of Timor-Leste.

This chapter examines the role political parties have played in promoting democracy in Timor-Leste. First, it documents the emergence of political parties in Timor-Leste since 1975. It then discusses the ideological spectrum and programs of the parties. This section also analyses party representation and the question of what is an effective number of parties in the new democracy. Next, the future of political parties in Timor-Leste is considered by evaluating their current positions and the potential for opposition parties to build coalitions. A conclusion is offered in the last section of the chapter.

\section{The emergence of political parties in Timor-Leste}

The emergence of political parties in Timor-Leste dates back to April 1974, when a military coup took place in Portugal. The coup leaders granted freedom to all Portuguese colonies, including Timor-Leste. Now able to decide their own future, five political parties emerged in Timor-Leste, namely Uniao Democratica de Timor (UDT); Associacao Social Democratica de Timor (ASDT), which later transformed into Fretilin; Associacao Popular Democratica de Timor (APODETI); Klibur Oan Timor Asuain (KOTA); and Trabalhista (Labour).

UDT's objective was to turn Timor-Leste into a federated state of Portugal with independence to come later. Fretilin wanted immediate independence, while APODETI aimed at integrating Timor-Leste into Indonesia as an autonomous state. KOTA and Labour wanted to maintain strong ties with Portugal.

The Portuguese Government planned to complete the decolonisation process in 1976, but UDT interrupted that timetable by staging a coup in August 1975. This was followed by a counter coup. On November 28, 1975, Fretilin unilaterally proclaimed the independence of Timor-Leste, precipitating the Indonesian invasion and occupation on December 5, 1975.

Under the dictatorship of Suharto, Indonesia ceased the activities of all TimorLeste-based political parties. The three Indonesian parties — Golkar, Indonesian Democratic Party (PDI) and United Development Party (PPP) — operated in the province without a strong following, although the people of Timor-Leste were forced to participate in the five-yearly election process, known in Indonesia as the 'festival of democracy'.

Even during the occupation, new parties - Partido Nacionalista Timorense (PNT) and Uniao Democratica Cristao (UDC) — did emerge in Timor-Leste and in exile, especially in Portugal. Further, in the 1980s, Xanana Gusmao, the leader of the resistance within Timor-Leste, established with another exiled resistance fighter, Jose Ramos-Horta, the Concelho Nacional da Resistencia Nacional (CNRM) to accommodate groups other than Fretilin who were resisting Indonesian rule. In 1998, CNRM was replaced by Concelho Nacional da Resistencia de Timor $\left(\right.$ CNRT) ${ }^{3}$ as the umbrella organisation of the resistance movement. CNRT gained large support internationally and domestically and, in elections on August 30, 1999, it was the CNRT flag, not Fretilin's, which was used at the ballot box. 
The Indonesian authorities, while not officially allowing the operation of parties other than the three registered blocs, did allow PNT to be established in 1999. A coalition of the UDC and Partido Democratico Crista (PDC) was established in Portugal in 1998 as a splinter of UDT. Subsequently, that coalition divided into two parties - UDC representing the Catholic wing and PDC the Protestant one - in order to be able to register separately to participate in the 2001 elections. Another party to emerge in the 1990s, during the Indonesian occupation, was Partido Socialista de Timor (PST). It conducted its activities underground.

It was when UNTAET began to organise the Constituent Assembly elections that political parties in Timor-Leste were revived. Sixteen parties registered to participate in that election (see Table 4.1). These included parties established during the Portuguese period, namely Fretilin, KOTA, Trabalhista and UDT. APODETI did not register but a breakaway faction, APODETI Pro-Referendum - founded in the 1990s to fight the Indonesian occupation - did. In addition, Associacao Social Democratica de Timor (ASDT) revived itself in 2001 and registered as a separate party from Fretilin with Francisco Xavier do Amaral, the founding president of both parties leaving Fretilin to resume his position as ASDT president.

Eight new parties emerged to participate in the 2001 elections. These were: the Liberal Party, Partido Democratico (Democratic Party or PD), Partido Democratico Cristao (PDC), Partido Povo Timor (PPT), Partido Social Democratica (PSD), Partido Democratico Maubere (PDM), Parentil and Uniao Democratica Crista/Partido Democratico Cristao (UDC/PDC).

Of the 16 registered political parties that stood for election in 2001, only 12 won enough votes to be represented in the Constituent Assembly (see Table 4.2).

\section{The ideology of political parties}

The history of Timor-Leste has been shaped by colonialism and occupation. When the elections were held, pro-independence parties attracted the support of the people, but ideology per se was of less influence. This is reflected by the dominance of Fretilin in the elections of 2001. With the independence issue resolved, however, a degree of ideological difference is emerging, even if all parties still have similar platforms.

The narrow ideological divide among the parties might be attributed to the fact that, with the exception of Fretilin, UDT and APODETI Pro-Referendum, all are newcomers to politics, and might represent regional elites rather than contending ideologies. ${ }^{5}$ Given that the elections of September 2001 were based more on emotional issues connected to the long Indonesian occupation and the suffering it caused and less on ideology and programs or the ability to govern, the new parties are still in the process of articulating their ideological positions.

The established party, Fretilin, has changed from a radical, revolutionary and leftwing party to a moderate one, with a less dogmatic ideology. Indeed, Fretilin might be facing something of a crisis in ideology now that it has to cope with new domestic and international circumstances. Its latest Political Manual ${ }^{6}$ strongly emphasises mainstream economics and liberal democracy, including multi-partyism. On the other hand, conser- 
Table 4.1: Political Parties in Timor-Leste, June 2004.

\begin{tabular}{|c|c|c|c|}
\hline Party & General Characteristics & & Year \\
\hline & Vision/Objectives & Origins & established \\
\hline ASDT & $\begin{array}{l}\text { Defence of independence, } \\
\text { democracy and pluralism. }\end{array}$ & $\begin{array}{l}\text { From ASDT to Fretilin } \\
\text { then ASDT }\end{array}$ & $1974 / 2001$ \\
\hline Fretilin & $\begin{array}{l}\text { Independence and democracy } \\
\text { based on social justice. }\end{array}$ & From ASDT & $1974 / 2001$ \\
\hline KOTA & $\begin{array}{l}\text { Defence of an independent, sovereign } \\
\text { and stable state with balance of power. }\end{array}$ & Strong ties with UDT & $1974 / 2000$ \\
\hline Liberal & Liberal and individual rights at centre. & Youth movement & 2001 \\
\hline PD & $\begin{array}{l}\text { Nation-building based on freedom, democracy } \\
\text { and a just society. }\end{array}$ & $\begin{array}{l}\text { Fretilin, Student and } \\
\text { youth movements }\end{array}$ & 2001 \\
\hline PDC & $\begin{array}{l}\text { Build a society within peace, } \\
\text { democracy and justice. }\end{array}$ & $\begin{array}{l}\text { Splinter of } \\
\text { UDC/PDC }\end{array}$ & 2000 \\
\hline PNT & Democracy. & Splinter of Fretilin & $1999 / 2001$ \\
\hline PPT & n.a. & Several parties & 2001 \\
\hline PSD & $\begin{array}{l}\text { Creating a state based on national } \\
\text { unity and consensus. }\end{array}$ & $\begin{array}{l}\text { Splinter of Fretilin } \\
\text { and UDT }\end{array}$ & 2000 \\
\hline PST & $\begin{array}{l}\text { A socialist \& classless state free from } \\
\text { colonialism, imperialism and exploitation. }\end{array}$ & Splinter of Fretilin & 2000 \\
\hline UDC & Establishment of democratic system. & Splinter of UDT & $1998 / 2001$ \\
\hline UDT & Democracy and justice. & First party in East Timor & $1974 / 2001$ \\
\hline Trabalhista & Democracy to eliminate exploitation. & & $1974 / 2001$ \\
\hline Povu Maubere & n.a. & $\begin{array}{l}\text { APODETI } \\
\text { Pro-Referendum }\end{array}$ & 2001 \\
\hline Parentil & n.a. & Splinter of Fretilin & 2001 \\
\hline $\begin{array}{l}\text { APODETI-Pro- } \\
\text { Referendum }\end{array}$ & $\begin{array}{l}\text { Defence of democracy, tolerance } \\
\text { and non-violence. }\end{array}$ & Splinter of APODETI & 2001 \\
\hline
\end{tabular}

vative parties such as UDT have maintained their ideology largely consistently since the 1970s, paying more attention to the role of traditional authorities.

If we place political parties in Timor-Leste along a left-right axis, we can identify three groupings at the left, centre and right; and then three further parties (PDC, PNT and PPT) without clear ideologies or stated platforms. The most left-wing party is the Socialist Party of Timor (PST), which aims for a socialist and classless state. Other parties ideologically close to PST are Fretilin and ASDT.

Fretilin started out as a revolutionary movement that later became a political party calling for radical changes in Timor-Leste society, although, as mentioned above, its stance has been tempered by the realities of independence. Fretilin wants a free and mandatory school system and, in regard to health policy, advocates the use of 'green' (traditional) medicine. It argues that Timor-Leste should become a member of the International Socialist Organisation of centre-left parties around the world. 
Table 4.2: Political Parties in Timor-Leste, May 2001.

\begin{tabular}{|c|c|c|c|}
\hline Party & Selected principles and policies & Tendency & President \\
\hline ASDT & $\begin{array}{l}\text { Liberal politics and open market economics, } \\
\text { attention to veterans of independence. }\end{array}$ & Centre-left & $\begin{array}{l}\text { Francisco Xavier } \\
\text { do Amaral }\end{array}$ \\
\hline Fretilin & $\begin{array}{l}\text { Revolutionary. Mandatory and free primary education, } \\
\text { agriculture, cooperatives, literacy, natural resources and } \\
\text { foreign investment. Membership in ASEAN and } \\
\text { South Pacific Forum. }\end{array}$ & Left & $\begin{array}{l}\text { Francisco } \\
\text { 'Lu-Olo' } \\
\text { Guterres }\end{array}$ \\
\hline KOTA & $\begin{array}{l}\text { Promote culture and tradition, agriculture, tourism } \\
\text { and good relations with neighbouring countries. }\end{array}$ & Right & $\begin{array}{l}\text { Leao dos reis } \\
\text { Amaral }\end{array}$ \\
\hline Liberal & $\begin{array}{l}\text { Individual freedom, government should not intervene } \\
\text { in economy, business and trade. }\end{array}$ & $\begin{array}{l}\text { Extreme } \\
\text { right }\end{array}$ & $\begin{array}{l}\text { Armando } \\
\text { da Silva }\end{array}$ \\
\hline PD & $\begin{array}{l}\text { Democracy, pluralism and individual rights. Market economy } \\
\text { with selective intervention of the Government. Transparent } \\
\text { and responsible government. Membership in ASEAN and } \\
\text { South Pacific Forum. Mandatory primary schooling, recognition } \\
\text { of veterans, primary health care and standardisation of Tetum. } \\
\text { Investment policy with attention to small and medium } \\
\text { enterprises. Priority on agriculture, poverty reduction and } \\
\text { elimination of famine. }\end{array}$ & Centre & $\begin{array}{l}\text { Fernando } \\
\text { 'Lasama' } \\
\text { de Araujo }\end{array}$ \\
\hline PDC & $\begin{array}{l}\text { Christian values. People-oriented economy and } \\
\text { universal health policy. }\end{array}$ & $\begin{array}{l}\text { Unclear. } \\
\text { Seems to be } \\
\text { centre-left }\end{array}$ & $\begin{array}{l}\text { Olinda } \\
\text { Guterres }\end{array}$ \\
\hline PNT & Investment and Bahasa Indonesia as official language. & $\begin{array}{l}\text { Unclear. } \\
\text { Seems to } \\
\text { be centre-left }\end{array}$ & $\begin{array}{l}\text { Abilio } \\
\text { de Araujo }\end{array}$ \\
\hline$\underline{\text { PPT }}$ & Not available. & Not available & Jacob Xavier \\
\hline PSD & $\begin{array}{l}\text { Minimum wage and state role in economic development. } \\
\text { Prioritise education, health, housing and good governance. } \\
\text { Membership in ASEAN and South Pacific Forum. Oppose } \\
\text { death penalty and abortion. }\end{array}$ & Centre-right & $\begin{array}{l}\text { Mario Viegas } \\
\text { Carrascalao }\end{array}$ \\
\hline PST & $\begin{array}{l}\text { Socialist and classless state. Compulsory education, } \\
\text { development of Tetum, divorce legalised and equality } \\
\text { between men and women, equal distribution of land, free } \\
\text { and universal health system, against death penalty. }\end{array}$ & Extreme-left & Pedro Soares \\
\hline UDC & $\begin{array}{l}\text { Establishment of democratic system and Christian } \\
\text { humanism,market economy, basic education and free } \\
\text { health care, and promotion of local culture. Membership } \\
\text { of ASEAN, CPLP, and other democratic regimes. }\end{array}$ & Right & Vicente Guterres \\
\hline UDT & $\begin{array}{l}\text { Just distribution of income, centralised system of } \\
\text { government, pensions for retired FALINTIL widows and } \\
\text { orphans, also for ex-Portuguese and Indonesian civil servants. } \\
\text { Application of customary law and role of elders in } \\
\text { solving problems. }\end{array}$ & Right & $\begin{array}{l}\text { Joao Viegas } \\
\text { Carrascalao }\end{array}$ \\
\hline
\end{tabular}

Source: Political parties' manuals, speeches of party leaders, and Walsh. ${ }^{4}$ 
ASDT has made a dramatic shift to the right. Its party manual states that, while still a vanguard party, it values liberal politics and an open market economy. This is very different from ASDT's initial position in 1974 when it was established as a leftist party (becoming further radicalised when it was absorbed into Fretilin). Now, ASDT is seeking to establish itself as a centre-left party, which embraces mainstream political and economic ideas. ADST's leader is Francisco Xavier do Amaral, the man who founded the party and then became President of Fretilin, until he was captured and imprisoned first by antagonistic Fretilin cadres and then by the Indonesians. Unable to return to this position after independence, he decided to revive ASDT as his personal political vehicle.

The party most clearly on the right is the Liberal Party, which values individual freedom and argues against any state intervention in the economy. Other parties apparently tilting to the right - despite not yet fully defining their positions — are UDT, UDC and KOTA.

UDT was a large party in 1974, but, in 2001, was among the smaller ones, with its leadership - made up of former bureaucrats who had worked for the Portuguese Colonial Government and traditional village heads - having partly contributed to its decline in support. Apart from having shifted from its original position that Timor-Leste should be a federated state of Portugal to joining the CNRT in the 1990s, its ideological stance is little changed. It is a strong proponent for the application of customary law and of a significant role for elders in the nation's governance.

UDC and KOTA are both splinters from UDT. UDC talks about Christian humanism, with an emphasis on democracy and justice. It is market oriented but, like UDT and KOTA, defends local culture and tradition. KOTA is a strong proponent of Timor-Leste as a federation of kingdoms.

Two new parties - the Democratic Party (PD) and Social Democratic Party (PSD) - seem to be placing themselves at the centre. PD was founded just two months before the elections of September 2001. It was formed by former students, intellectuals and clandestine activists who were disenchanted with Fretilin tactics and ideology:

There was resentment against the returned Fretilin exiles, such as the party's secretarygeneral, Mari Alkatiri, because they were perceived as arrogant, privileged, and authoritarian ... They were seen as marginalizing the younger generation who were educated in Indonesian. They were also discounting the contribution of the student movement and of urban East Timorese against Indonesian rule, e.g., the demonstrations in 1991 that drew worldwide attention to human rights violations perpetrated by the Indonesian army. ${ }^{7}$

The Democratic Party (PD) is also strengthened by intellectuals educated in the West, especially in Australia, the US, UK, Portugal and Indonesia. Another major component of PD are middle-level resistance figures, many of whom came from the clandestine Internal Political Front (FPI) of the CNRT and had therefore held leadership positions at district, subdistrict and village level. Many among this group were members of Fretilin but opted for PD because of its spirit of national unity and inclusiveness. 
PD managed to attract the second-largest number of votes after Fretilin and is currently the main opposition party in the Parliament, with seven seats. Although PD's ideas are still in the formative stages, its position tends towards left of centre. It supports mandatory primary schooling and calls for assistance to veterans of war and war victims. It is in favour of a market economy with selective intervention from government. In his latest policy speech, the President of PD, Fernando 'Lasamo' de Araujo, stressed the development of an investment climate that favoured small and medium enterprises through tax incentives and less regulation. ${ }^{8}$ The PD, however, suffers from leadership problems and lacks a systematic policy approach to managing the country. This might be explained partly by the lack of experience of its leaders in governance matters, drawn as they are from the ranks of political activists.

The Social Democratic Party (PSD) is also in the central grouping, although it is still grappling with its precise orientation. It defends minimum-wage policy and state intervention in economic development, and is against the death penalty and abortion. Younger leaders have also been arguing that the PSD should approach the International Socialist Organisation. It is interesting to note that the PSD has attracted supporters from UDT, which might have reduced the latter's votes in the 2001 elections.

The remaining three parties in the National Parliament do not have clear positions on socioeconomic matters. The Partido Povu Timor (PPT), whose supporters come mainly from Hatudu, a subdistrict in Ainaro District, is sympathetic to a kingship model of governance.

Religious orientation has not been a particularly influential factor in contemporary Timor-Leste politics. Most parties, including the major ones such as Fretilin, PD, PSD and ASDT, defend the idea of a secular state and the separation of church and state. Even the parties that have adopted Christian references in their names - Uniao Democratica Crista (UDC) and Partido Democratico Crista (PDC) - do not articulate their religious beliefs strongly and have only three seats in the Parliament.

Similarly, attachment to customary law and traditional kingdoms have so far been peripheral election issues, though it remains to be seen if these will emerge as more significant matters in the future. At the moment, however, KOTA, with its platform based on kingship, and UDT, which wants to see elders play a role in national affairs, have only two seats each in the Parliament.

With regards to foreign policy, most parties view ASEAN favourably for security and trade reasons. This represents a shift from the view in 1999, when Timor-Leste leaders, especially Jose Ramos-Horta (at the time, the CNRT's foreign spokesman), stated that an independent Timor-Leste would become part of the South Pacific Forum. Now, the PD has a firm position on joining ASEAN, and PSD has also indicated that membership would be desirable. Fretilin still has reservations, given Indonesia's prominence in ASEAN. Nevertheless, the current Fretilin Government has developed a strong relationship with Malaysia, which might facilitate entry into the grouping. 


\section{Fretilin dominance and the opposition of PD and PSD}

Timor-Leste has a multi-party system with 12 parties represented in the National Parliament. UNTAET Regulation 2001/01 determined a unicameral Constituent Assembly (later called the National Parliament), with 88 seats, of which 75 were contested through party lists, and the remaining 13 seats were allocated to the districts and elected on the basis of proportional representation.

The results of August 30, 2001, elections saw Fretilin emerge as the majority party with 55 seats, while the rest of the seats were divided among 11 other parties (see Table 4.3), with the next largest party, the Democratic Party (PD), gaining seven seats, followed by ASDT and PSD securing six seats each.

Table 4.3: Timor-Leste: Parties in the National Parliament.

This figure shows the number of seats held by each party and their political orientation, from left to right.

\begin{tabular}{lccccccccccc}
\hline PST & Fretilin & PNT & ASDT & PD & PSD & UDT & KOTA & PPT & PDC & UDC & Liberal \\
\hline 1 & 55 & 2 & 6 & 7 & 6 & 2 & 2 & 2 & 2 & 1 & 1 \\
\hline
\end{tabular}

Why did Fretilin gain such a majority? Several factors can explain the outcome. First, it is the party that has consistently defended independence since 1974. Anecdotal evidence suggests that people thought Fretilin should be rewarded for this position, although people also encouraged their children to vote for other parties. This does not completely explain Fretilin's victory given that the party had experienced leadership problems and a weakened organisational structure, especially in the late 1970s and early 1980s, when it suffered crushing military defeats against Indonesia. There were also atrocities associated with Fretilin leaders during the same period, which reduced its influence. And then Xanana Gusmao and Jose Ramos-Horta decided to form the CNRM to unify all resistance forces fighting against Indonesia. In 1987, Xanana Gusmao went further by declaring FALINTIL no longer a military wing of Fretilin but instead a nationalist force fighting against Indonesia. The change in FALINTIL's position was also a way to accommodate several guerrilla leaders who were not members of Fretilin. From the late 1980s, the resistance movement was revitalised and attracted more popular and international support compared with the exclusivity of Fretilin in the late 1970s and early 1980s. From there, the face of resistance changed forever and Xanana Gusmao became a national not just a party leader.

And so, secondly, there was the Xanana factor. Many voters, especially in rural areas, thought that Xanana was still the leader of Fretilin and that the elections were about choosing Xanana to be president. In fact, leading up to the elections, Xanana had stated that a big majority by Fretilin would not be healthy for democracy in TimorLeste. ${ }^{\text {ix }}$ This stance might well have prevented Fretilin winning the 88 per cent of votes predicted by the party's leaders, Francisco Lu-Olo Guterres and Mari Alkatiri.

Thirdly, there was, again particularly in rural areas, a fear of revenge if people did not choose Fretilin. In late 2000 and early 2001, Fretilin activated its dormant membership and completed a national registry of all militants and sympathisers. Some citizens felt there was high degree of intimidation in this process. ${ }^{10}$ 
At any rate, the results of the elections turned Fretilin into the dominant party in the Constituent Assembly and later the National Parliament, with major influence over the drafting of laws, including the Constitution. Fretilin's strength in the Legislature was further increased through its alliance with ASDT, PNT and PDC.

As mentioned above, it is the Democratic Party (PD) that represents the major opposition party in the Parliament. PD draws its support from the grassroots and the middle class. Recently, a number of intellectuals and former guerrilla leaders also joined the party. It is an open party that can accommodate people with different backgrounds and, as such, has the potential to become a serious alternative to Fretilin in the next election. A poll by the American-based International Republican Institute (IRI) in $2003^{11}$ showed that PD has gained 4 per cent support since 2001, especially among the youth and in the urban areas, despite not having staged any major activities since September 2001. The same poll shows that Fretilin has lost almost 5 per cent of voters and PSD has gained 2 per cent additional support.

The Social Democrat Party (PSD) is the second opposition party with six seats in the Parliament. Its leader, Mario V. Carrascalao, a former Portuguese official, TimorLeste Governor and ambassador under the Indonesian occupation, and Vice-President of CNRT, is a competent technocrat who could easily lead Timor-Leste. In addition, Carrascalao has a charismatic personality, which has been a major factor in attracting followers. PSD draws support from former UDT members, Fretilin, some clandestine and FALINTIL members and independents. The party could also emerge as a strong alternative party if it can overcome its internal divisions.

It is conceivable that PD and PSD could form a centre-right coalition in order to form a strong front against Fretilin and its allies. It was this idea that led both parties to spearhead the National Unity Platform in 2003 comprising five parties, including ASDT, a key Fretilin ally. Weighed down by conflicting agendas and personality politics, their platform never became a serious threat to Fretilin's dominance.

Fretilin and ASDT represent a centre-left coalition, although for the time being, as the dominant party, Fretilin does not need to rely on coalitions to secure the passage of any laws that require a simple majority. When it needs to get an absolute majority in the National Parliament, it can look to ASDT, PNT and PDC for support.

At present the alliances of political parties in the National Parliament are fluid. While it might be expected that parties such as PST at the extreme left would vote with parties of similar ideological persuasion — such as Fretilin and ASDT — in fact, PST often votes with centre-right parties such as PD and PSD. Similarly, the Christian parties do not always ally themselves with the centre-right parties. For example, PDC regularly votes with Fretilin. The conclusion we can draw from this is that the party system in Timor-Leste has not yet solidified along a left-right political spectrum.

\section{How many parties?}

What is an ideal number of parties in Timor-Leste? While the presence of 12 parties in the Parliament might appear excessive, four parties (Fretilin, PD, PSD, ASDT) control 84 per cent of the seats, with the remainder divided between eight minor parties. 
Interestingly, the Laakso/Taagepera Index, which measures the average number of parties for comparative purposes, notes that Timor-Leste has 2.44 effective parties. ${ }^{12}$

The small number of effective political parties reinforces the notion that the party system in Timor-Leste is not so fragmented as to cause serious problems of coordination. As Haggard notes, policy coordination requires time and incentives and can be undermined if there are too many coalitions that need to be juggled. ${ }^{13}$ In the case of Timor-Leste, a coalition system could be successful because there are only four effective parties. But for the time being, the strength of the governing coalition is unmatched because of Fretilin's sizeable parliamentary majority ( 65 per cent).

\section{The future of political parties}

What is the future of political parties in Timor-Leste? Fretilin's current supremacy leads some to argue that Timor-Leste could become a one-party state, similar to the situations in Malaysia and Singapore, where the United Malays National Organisation (UMNO) and the People's Action Party (PAP), respectively, are dominant. This is a distinct possibility for the following reasons.

First, the Opposition is being weakened through direct and indirect intimidation. For example, civil servants who attended opposition party activities, especially those of the Democratic Party, during holidays in Suai in March 2004, have been suspended. In the same month, PSD activity in Uatu-Lari, Viqueque, was disbanded by local authorities and police. In addition, when accusations of bribery were made about Prime Minister Mari Alkatiri, the Government suggested the Opposition was behind the claims. Similarly, when former Commander L-7, the alias of Cornelio Gama, a former FALINTIL commander who fought against Indonesia for 24 years, staged a demonstration in July 2004, demanding wide-ranging reforms in the police and in the Government, the Government's response was to use force to disband the demonstration and to claim that L-7 had been used by the Opposition — in particular, Mario Carrascalao, head of the PSD and a Fretilin rival since the 1970s. In the words of Prime Minister Alkatiri, 'L-7 is not the culprit in this regard. It is the opposition who have used him for political purposes. So we will take care of them.' ${ }^{14}$

Secondly, there has been persecution of the media: for example, when the Government attempted to relocate the Suara Timor Lorosae newspaper from its current premises because it was running stories critical of the Government. Individual journalists have also been threatened.

Thirdly, the current leadership of Fretilin is controlled by the Mozambican clique led by Alkatiri. With few exceptions, this group has been exposed to the dictatorial practices of the African continent of failed states and vast poverty. One of the frequent explanations for sustained poverty in Africa is that despotic regimes run their countries by stealing public wealth. The tendency towards working without consultation is demonstrated by Fretilin's refusal to take any constructive part in the CNRT after 2000. Fretilin had always seen the CNRT as a threat to its power. The disbandment of the CNRT therefore offers Fretilin further opportunity to forge itself into a dominant party. 
There are, however, also reasons why Fretilin might not remain as powerful as it is today. The electorate is already growing disenchanted. While the Fretilin Government benefited from the unqualified support of the international community during the reconstruction period, more recently there has been a decline in international aid and economic growth, as well as increased unemployment. These trends are being reflected in reduced support for the party, which, according to IRI polling in 2003, is about 50 per cent, down 7 per cent from the results of the 2001 elections. As noted above, that support is being transferred to the Democratic and Social Democratic parties. Early indications of the village head (chefi suco) elections in Maliana and Oe-Cusse districts in December 2004 were that very few Fretilin candidates were elected as heads of villages - this despite Fretilin often being the only party to put up candidates, because other parties encountered bureaucratic obstacles to even registering to participate in the poll. Thus, most of the other candidates were independents, possibly associated with opposition parties.

Fretilin's national leaders, especially Francisco Lu-Olo Guterres (the party's president as well as President of the National Parliament) and Mari Alkatiri (its secretary -general and Prime Minister) are not popular. The IRI polling shows Lu-Olo's popularity rating at 64 percent, well below the 68 per cent for Mario Carrascalao (PSD President) and also below other prominent political leaders such as Jose Ramos-Horta (Minister of Foreign Affairs and Cooperation), Taur Matan Ruak (Commander of Armed Forces) and Xanana Gusmao (Timor-Leste's President). Mari Alkatiri's rating is even worse, at less than 50 per cent. Incumbency, lack of personal appeal and incompetence might have contributed to the decline in popularity of these two leaders. After all, the dominance of Fretilin in the last legislative elections is arguably less about the quality of its leaders and more about the party's long standing in the struggle for independence.

Looking to the next parliamentary elections in 2006, it must be noted that the Xanana factor, as at least an indirect vote-getter for Fretilin in 2001, will not exist. Even in the presidential elections in April 2002, the differences between Fretilin and Xanana Gusmao were obvious and became amplified when Fretilin leaders urged voters to vote for both presidential candidates, namely Xanana Gusmao and Francisco Xavier do Amaral. Mari Alkatiri went further, urging voters to destroy the ballot - a call that drew criticism from observers. ${ }^{15}$ It is also to be hoped that the fear of not voting for Fretilin will have dissipated.

Finally, the 2001 elections were characterised by emotion. Campaigns were not based on the quality of programs and candidates. People chose Fretilin reward it regardless of its leadership quality and is platform. In the next elections, the opposition, especially PD and PSD, will be better organised. Both parties have been active in districts across Timor-Leste. Recently, PD commemorated its third anniversary in Samaletek (Ermera), a former Fretilin stronghold. Such activities will intensify as the election year approaches. In addition, a new party, comprised of resistance veterans and intellectuals educated in the West, might also emerge and appeal to voters, including those who voted for Fretilin in the past. 
Fretilin leaders are not popular, strong or capable enough to forge a single dominant-party state as Lee Kuan Yew did in Singapore and Mahathir Mohamad and his predecessors did in Malaysia. Indeed, without the UN presence in Timor-Leste during the past three years, the Government of Fretilin might well have not survived, especially after the riots of December 2002.

Fretilin might still win in 2006, albeit with the likelihood that its majority will be reduced, however, should the party engage in tactics of intimidation, vote-rigging and money politics in future campaigns, it might maintain its current levels of control, although these strategies will necessarily challenge its legitimacy. Unfortunately, there is already evidence of government intimidation as noted above. And Fretilin is building up a war chest unmatched by opposition parties. Money alone, however, cannot buy votes. This was demonstrated in the 1999 referendum, when Indonesia tried to buy voters but failed. The people of Timor-Leste took the money but walked away by voting for independence.

\section{Conclusion}

Political parties in Timor-Leste emerged in response to the 1975 military coup in Portugal, with domestic hopes for a democratically governed state for Timor-Leste. But they had little opportunity to become established in the country, given that during the Indonesian occupation, all the Timor-Leste-based political parties were disallowed. They began to flourish only after UNTAET initiated the 2001 Constituent Assembly elections. Those elections resulted in Fretilin becoming the government party, with 11 other parties represented in the Constituent Assembly. Later, the Constituent Assembly transformed itself into the National Parliament. Thus, Timor-Leste now operates on a multi-party system, albeit with only a small number of effective players. The ideology of the political parties is informed primarily by socioeconomic issues, with positions held across the left-right spectrum but with a convergence towards the centre.

As far as the future of political parties in Timor-Leste is concerned, it is likely that Timor-Leste will not be a single-party state unless intimidation, vote-rigging and money politics are used in the 2006 elections. Instead, it is to be hoped that the main opposition parties can develop coherent party platforms that will be able to compete with those of the Fretilin Government, especially now that the high emotions of newly and bloodily acquired independence are replaced by a more sober mood in the electorate.

\section{Footnotes}

1 I thank Paulino F. Guterres for research assistance and Roland Rich, CDI, ANU, Australia, for supporting this research. All errors are mine.

2 See Gorjao, Paulo. 2002. 'The Legacy and Lessons of the United Nations Transitional Administration in East Timor.' Contemporary Southeast Asia, Vol. 24, No. 2. pp. 313-36. 
3 The CNRT comprised three fronts, namely the armed wing, Forcas Armadas para Libertacao Nacional (FALINTIL), the clandestine wing named Internal Political Front (FPI, a Portuguese abbreviation), and the diplomatic front.

4 'KOTA: Manifesto aos Membros do Partido e aos seus simpatisantes (Novembro 2000).' Dili; 'Manifesto Politik PST.' 1999, Unpublished (political pamphlet); 'Manual Politik Partido Democrata Cristao.' Juli-2003; Partido Associacao Social Democrata Timorense (ASDT). 2003. Eastatuto: Republica Democratica de Timor-Leste; 'Resultado do I Congresso Nacional do Partido Social Democrata de Timor Leste (6-8 de Novembro de 2003).' Dili; 'Komemorasaun Tinan Partido Socialista de Timor (1999-2000).' Aileu-Atsabe; Manual Politico da Fretilin e Estatuto. Aprovado No. 1 Congresso Nacional Extraordinario da Fretilin. Dili, 10-15 de Julho de 2001; Lasama de Araujo, Fernando. 2004. 'Forsa PD: Hamutuk ho Povu Hari Nasaun (Go PD: Together with People Build the Nation).' Political Speech. Samaletek, Ermera, Timor-Leste, June 12; Walsh, Pat. 2001. 'East Timor’s Political Parties and Groupings.' Briefing Notes. April. Unpublished.

5 Walsh, Ibid.

6 Manual Politico da Fretilin e Estatuto, op. cit.

7 King, Dwight. 2003. 'East Timor's Founding Elections and Emerging Party System.' Asian Survey, Vol. 43, No. 5. California: University of California Press. p. 755.

8 Lasama de Araujo, op. cit.

9 For more discussion of the contention between Xanana and Fretilin leaders, see Smith, Anthony L. 2004. 'East Timor: Elections in the World's Newest Nation.' Journal of Democracy, Vol. 15, No. 2. pp. $145-59$.

10 Walsh, op. cit.

11 International Republican Institute. 2003. Public Opinion Poll. Dili, Timor-Leste.

12 Laakso, M. and Rein Taagepera. 1979. 'Effective number of parties: a measure with application to Western Europe.' Comparative Political Studies, Vol. 12. pp. 3-27; Saldanha, Joao M. 2003. 'Political Party and Electoral System.' Module 5 Basic Leadership Training. Dili: Timor Institute of Development Studies.

13 Haggard, Stephan. 2000. 'Interests, Institutions, and Policy Reform.' In Anne Krueger (ed.), Economic Policy Reform: The Second Stage, Chicago: University of Chicago Press. pp. 1-60.

14 Suara Timor Lorosae, July 21, 2004.

15 Smith, op. cit. 